\title{
INTRAVENOUS SOLUTION THERAPY
}

\section{SIMPLIFIED}

\section{RATIONALISATION OF FORMULATIONS AND PACKS}

\author{
DR. G.W. SCHEPERS
}

\section{OPSOMMING}

Die Adviserende Komitee oor Gesondheidsake het 'n Nasionale Intraveneuse Ingieting Rasionaliseringskomitee aangestel om beskikbare intraveneuse oplossings te ondersoek en aanbevelings te maak ten einde pasiëntveiligheid te bevorder, behandeling te vereenvoudig en groter ekonomie te bewerkstellig. Die aanbevelings van die komitee maak voorsiening vir 'n vermindering van die verskeidenheid formules van 103 na 41 en houers van meer as 70 na 21. Die Komitee vra vir kommentaar, kritiek en advies voordat die aanbevelings geïmplementeer word.

\section{INTRODUCTION}

The Health Matters Advisory Committee, a statutory body constituted under the Health Act 63 of 1977, appointed a National Intravenous Infusion Rationalisation Committee, consisting of experts from the medical and pharmaceutical professions to investigate and make recommendations regarding the availability and use of intravenous solutions in South Africa with the view to promoting patient safety, simplifying therapy for the clinicians, and providing economy for both the producer and the consumer. When the recommendations are implemented the range of formulations will be reduced from 103 to 41 (See Table 1) and containers from over 70 to 21 . Considerable modification will result in improvements and ultimate standardisation of administration sets and packs.

Comment, criticism and advice will be welcomed by the Committee.

\section{NATIONAL COMMITTEE'S MAN- DATE}

A Government appointed National Committee was given the following mandate:

To rationalise and standardise for economic reasons:

(a) The number of formulations of intravenous fluids henceforth to be the only available solutions for use in the Republic of South Africa.

(b) The number of container sizes
- which will be limited.

(c) The number of administration sets.

(d) To attempt, for logical reasons, at grouping the available formulations to meet various clinical indications.

\section{RECOMMENDATIONS \\ Volumes}

$1000 \mathrm{~m} \ell$ only will be adopted as standard size.

$1000 \mathrm{~m} \ell$ pack to accept a $100 \mathrm{~m} \ell$ overfill and the $200 \mathrm{~m} \ell$ to accept a $50 \mathrm{~m} \ell$ overfill in order to accommodate admixtures as required. Certain imported solutions (e.g. Intralipid) to be acceptable as supplied e.g. in $500 \mathrm{~m} \ell$.

\section{Pack material}

Preference will be given to clear plastic containers wherever possible and glass containers will no longer be used except in those cases where the contents is incompatible with plastic.

\section{Markings and labels}

All intravenous solutions to be labelled in black or dark blue except that red labels or markings will signify potentially hazardous solutions such as:

- $5 \%$ saline solution;

- sterile water;

- $50 \%$ dextrose solution;

- peritoneal dialysis solutions;

- solutions for cystoscopy or irrigation;
- amino acid and intralipid solutions.

Sterile pyrogen-free solutions which are not for intravenous use are preferably to be packed in rigid, screw cap, easy-pour bottles which are not compatible with standardised intravenous administration sets.

\section{Energy substrates}

1. Carbohydrate: Dextrose is considered to be the safest, and to replace all other sugars such as fructose and invert sugar. Higher alcohols will no longer be acceptable.

2. Fats: One intravenous fat emulsion, that is $10 \%$ and $20 \%$ Intralipid is currently acceptable.

3. Amino acids: only synthetic laevo-rotatory amino acid solutions will be acceptable at the moment but acceptable specialised new solutions are anticipated in the near future and will need registration with the M.C.C. Local manufacturers of intravenous solutions have agreed not to produce formulations without consultation with and agreement of the Rationalisation Committee. It is not the intention of the Committee to stifle development and progress in the intravenous fluids field but merely to keep costs to a minimum and to eliminate outdated unneccesary duplicating solutions. 


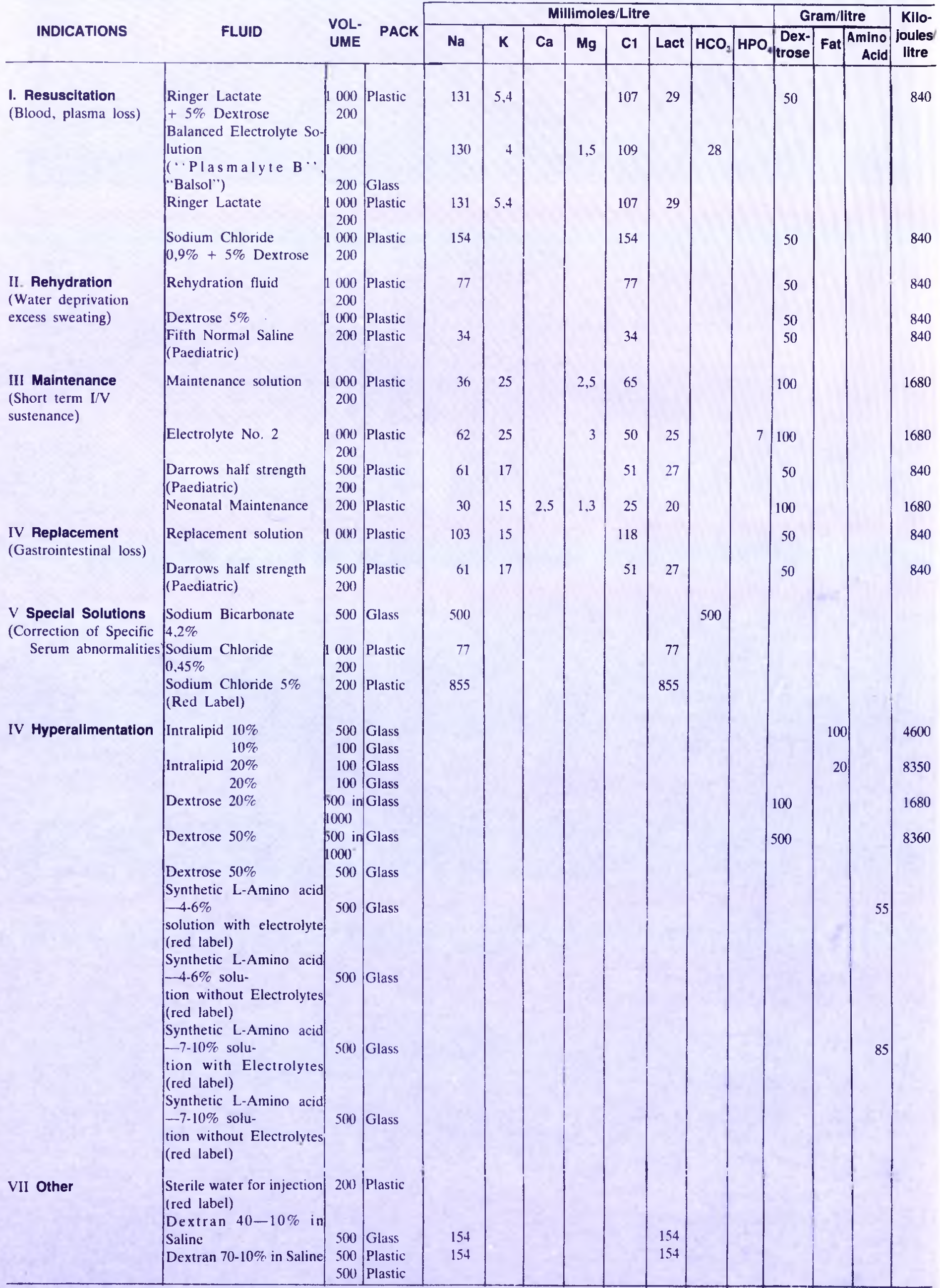


STANDARDISATION OF ADMI-

\section{NISTRATION SETS}

This will be the subject of a future report.

This Committee wishes to thank Prof. H.A. Grové, Director of Transvaal Hospital Services for organising this investigation, as well as the South African manufacturing firms of intravenous fluids, whose impartial contributions made our task much easier. Comments, criticism and advice will be welcomed by the Committee.
NATIONAL RATIONALISATION COMMITTEE FOR INTRAVENOUS SOLUTIONS

G.W. Schepers B.Sc. M B.Ch., (Chairman): Assistant Director. Hospital Services T.P. A., Private Bag X221, Pretoria J.B. Blignaut DIP, PHARM. (Secretary); Chief: Pharmaceutical Services. T.P.A. Pretoria

R. J. van Rooyen M.Sc. M.D. M.MED - Physician, H.F Verwoerd-hospital, T.P.A. Pretoria

H.C. Seftel M.B.B.Ch. D.MED - Physician, Johannes burg Hospital, T.P.A. Johannesburg

J.E. Crombrinck M B.B.Ch. D A - Anacsthetist, GaRankuwa Hospital. State Health Department

J.L. Couper M.B.B.Ch. F.F.A. - Anaesthetist, Ga-Ran kuwa Hospiral, State Health Department

P H. Krynauw Cilliers MB.B.Ch. F.C.S. (SA) M.MED. (Chir) - Surgeon, P.A.O., Bloemfontein

+ P.W. du Toit M.B.B.Ch. M. PRAX. MED. L.F.N. -

Anaesthetist. P.A.O. Blcemfontein

+ M.J. Ungerer M. B. B.Ch M.MED. L.F.N - Anaesthe tist. P.A.O. Bloemfontein

D.P. Myburgh MB B.Ch. F.C.P. - Physician, S.A. Defence Force. Pretoria.

A.F. van Eeden MB. B.Ch. L.F.N. M Med. - Anaesthe tist, S.A. Defence Force. Pretoria

M. Goodwin MB.B.S.F.F.A.R.C.S. - Anaesthetist. Add ington Hospital, N.P.A., Natal

+ C. de W. Vivier M. B. B.Ch - Superintendent. Tygerbers

Hospital, C.P.A. (Previous Chairman) Cape

D M. Dent M.B.B.Ch. F.C.S. (SA) F.R.C.S.Ch.M. - Sur-

geon, Groote Schuur, C.P.A., Cape

$\uparrow$ A.W. Durandt DIP. PHARM. (Previous Secretary)

C.P.A. Cape

N.D. Burman MB.B.Ch. M.R.C.P. - Physician. C.P.A Cape

J.C. Thom MB .Ch. M.MED. - Pacdiatrician, University of Stellenbosch. Cape

† J.F. Biebuyck M.B.B.Ch. F.F.A. (SA) Anaestherist

C.P.A. Groote Schuur. Cape

† P. Forster M.B.B.Ch. D.A.R.C.P. Lond R.C.S. Eng.

D. A.R.C.P. - IRE. Anaesthetist, Tygerberg. C.P.A. : Cape

- T.J.V. Voss M.B.B.Ch. D.A.R.C.P. Lond. RCS Eng.

Paed. Anaesthetist Red Cross Hospital, C.P.A., Cape

* (By invitation)

(Previous members)

\section{REPRESENTATIVES FROM MANUFACTURING FIRMS}

REMEDIA: E Bratı, G. McGee.

SABAX: H. Bernstein. F. Erasmus, K. Frizelle

LABETHICA: F. Noades. P. van der Merwe. B Sachs.

Robertson, Mrs. A. van der Zwan

\section{SYMPOSIUM PAPERS}

\section{SIMPOSIUM REFERATE}

The papers delivered at the symposia held in celebration of the 25th anniversary of the degree course in Nursing at the University of Pretoria, are available from the publication section of the S.A. Nursing Association (Private Bag X105, Pretoria, 0001). These addresses are recommended for stimulating ideas on nursing in the South African context.

The papers are published in the language in which they were delivered and appear in three parts:

\section{NURSING PREPAREDNESS $-\mathbf{R 3 , 9 5}$}

Includes preparedness in the home such as home accidents and emergency nutrition as well as preparedness during disaster situations which deals with the clinical evaluation and transportation of patients and how to handle various types of injuries.

\section{CREATIVITY IN NURSING EDUCATION - R3,00}

These papers deal with creativity in giving and evaluating nursing education. They were written by prominent South African nurses.

\section{THE QUALITY OF PATIENT CARE - R3,15}

The importance of the following in providing quality patient care are discussed: educational objectives, standards of patient care, measuring quality, job satisfaction, creative nursing administration and research.

The price of a complete set of papers is $\mathrm{R} 10,00$.
DIE referate van die simposia, wat gehou is ter viering van die 25ste verjaardag van die graadkursus in verpleegkunde aan die Universiteit van Pretoria, is by die publikasieafdeling van die S.A. Verpleegstersvereniging, (Privaatsak X105, Pretoria, 0001), beskikbaar.

Die referate word gepubliseer in die taal waarin hul gelewer is en verskyn in drie dele.

\section{VERPLEEGKUNDIGE PARAATHEID - R3,95}

Sluit paraatheid in die huis soos tuisongelukke en noodvoeding in, asook paraatheid tydens 'n noodsituasie wat handel oor die klinise evaluering en vervoer van pasiënte sowel as die hantering van verskillende tipes beserings.

\section{KREATIWITEIT IN VERPLEEGONDERWYS - $\mathbf{R 3 , 0 0}$}

Die referate handel oor vindingrykheid in die gee en evaluering van verpleegonderrig en is gelewer deur vooraanstaande Suid-Afrikaanse verpleegopvoedkundiges.

\section{DIE GEHALTE VAN PASIËNTSORG - R3,15}

Die belang van die volgende vir die lewering van 'n goeie gehalte van pasiëntsorg is bespreek: opvoedkundige doelwitte; pasiëntsorg-standaarde; kwaliteitsmeting; werksbevrediging; vindingryke verpleegadministrasie en navorsing.

Die prys vir 'n volledige stel van die referate is R10,00. 